\title{
Medical simulation - innovation in nursing education
}

\author{
Medical simulation - innovation in nursing education
}

Joanna Girzelskaa ${ }^{1}$, Ewa Guz ${ }^{1}$, Magdalena Nieckula² ${ }^{2}$ Marek Dąbrowski ${ }^{3}$

\author{
'Wyższa Szkoła Ekonomii i Innowacji w Lublinie, Wydział Nauk o Człowieku/ \\ University of Economics and Innovation in Lublin, Faculty of Human Sciences, \\ 2Podhalańska Państwowa Uczelnia Zawodowa w Nowym Targu, Instytut Nauk o Zdrowiu/ \\ Podhale State College of Applied Sciences in Nowy Targ, Institute of Health Sciences \\ 3Uniwersytet Medyczny im K. Marcinkowskiego w Poznaniu, Katedra i Zakład Edukacji Medycznej/ \\ Poznan University of Medical Sciences, Chair and Department of Medical Education \\ Joanna Girzelska: 0000-0002-5537-0987 \\ Ewa Guz: 0000-0002-0507-2172 \\ Magdalena Nieckula: 0000-0001-8897-5774 \\ Marek Dąbrowski: 0000-0003-2936-891X \\ CORRESPONDING AUTHOR/AUTOR DO KORESPONDENCJI: \\ Joanna Girzelska \\ Wyższa Szkoła Ekonomii i Innowacji w Lublinie, \\ Wydział Nauk o Człowieku \\ ul. Projektowa 4, 20-209 Lublin \\ e-mail: joannagirze@gmail.com
}

STRESZCZENIE

Słowa kluczowe:

ABSTRACT

Key words:

\section{SYMULACJA MEDYCZNA - INNOWACJA W KSZIAKCENIU PIELEGNIARER}

Cel pracy. Analiza wpływu symulacji edukacyjnej na poziom wiedzy, umiejętności i kompetencji studentów pielęgniarstwa.

Metody. W badaniach zastosowano metodę niesystematycznej analizy piśmiennictwa. Do analizy zaklasyfikowano literaturę, z której wyłoniono treści dotyczące wpływu symulacji edukacyjnej na proces kształcenia studentów pielęgniarstwa. Podczas kwalifikacji czasopism wykorzystano wyszukiwarkę Google Scholar. Korzystano z artykułów opublikowanych w elektronicznych bazach danych: EBSCOhost, MEDLINE, ScienceDirect.

Wnioski. Kształcenie prowadzone z wykorzystaniem symulacji edukacyjnej w pielęgniarstwie nie tylko zwiększa poziom wiedzy, umiejętności i kompetencji studentów ale też podnosi jakość opieki nad pacjentami i wpływa na wzrost ich bezpieczeństwa.

symulacja, pielęgniarstwo, edukacja, innowacja

\section{MEDICAL SIMULATION - INNOVATION IN NURSING EDUCATION}

Aim. Analysis of the impact of educational simulation on the level of knowledge, skills and competences of nursing students. Methods. The research used a non-systematic literature analysis method. Literature was classified for analysis, from which the contents on the impact of educational simulation on the education process of nursing students were selected. During the qualification of the magazines Google Scholar was used. Articles published in electronic databases were used: EBSCOhost, MEDLINE, ScienceDirect.

Conclusions. Education conducted using educational simulation in nursing not only increases the level of knowledge, skills and competences of students but also increases the quality of patient care and their security.

simulation, nursing, education, innovation 


\section{INTRODUCTION}

Changes in healthcare, the growing population of the elderly, and activities aimed at improving the quality of medical services, as well as the emphasis on increasing patient safety, constitute challenges which require an open and frank dialogue between healthcare organisations, teachers, and students. Those challenges require bold and risky solutions and necessitate innovation to gain educational experience, which allows educating professional nurses, translating ultimately into the high quality of healthcare provided to patients.

Innovation is not a new concept for this profession. Nurses are involved in innovative actions every day around the world. This stems from the desire to improve the quality of patient care. Furthermore, nurses innovate to obtain information, find better ways to promote health, prevent diseases, and to improve teaching and learning methods $[1,2]$.

The challenges which modern nursing faces are multifaceted and include staff shortage and the quality of education and clinical practice. As evidenced by research, the time students spend on clinical education does not necessarily correlate with the high-quality learning aimed to prepare students for practice [3]. Also, one may not be certain that this time includes only rich educational experiences which prepare students for their future work [4]. The need to meet the existing healthcare needs and current educational challenges in nursing have contributed to an increase in the use of medical simulation in education, as an innovative teaching method ensuring high quality, consistent, and repeatable clinical experiences [5].

The introduction of simulation-based teaching and learning of medicine, nursing and patient care was one of the major steps in the education of nurses and midwives. Simulation is a term which refers to an artificial reality created in the real world; it aims to achieve educational goals through empirical learning, while simulation tools constitute an alternative to real patients. Medical simulation is a method of education which makes use of educational equipment of varying degrees of sophistication, from simple trainers used to learn simple tasks, through nursing mannequins, to advanced patient simulators which faithfully imitate the human body and its physical characteristics and physiology typical of a given age. Simulation not only increases the competences of nursing staff but can also improve patient safety. Students can, on demand and depending on their needs, reconstruct many of the clinical situations associated with patient care in simulated conditions, from non-invasive to invasive procedures. They can improve their skills in a safe, risk-free environment [6].

\section{AIM}

This work aimed to analyse the impact of educational simulation on the knowledge, skills, and competences of nursing students.

\section{METHOD}

A non-systematic literature analysis method was applied in the research. The literature classified into the analyses included content concerning the influence of educational simulation on the process of education of nursing students. Google Scholar was used during the qualification of the journals. Articles published in electronic databases: EBSCOhost, MEDLINE, and ScienceDirect, were used. Papers published in 2015-2019 were selected for research. In total, 65 articles in English and 35 articles in Polish were analysed. From among 100 articles, 20 were selected, meeting the inclusion criteria for further analysis. Four keywords were used to qualify the literature: simulation, nursing, education, and innovation.

\section{RESULTS}

Simulation is a modern educational method used in both academic centres and healthcare institutions. From technology-rich, high-fidelity simulation scenarios to basic skills training using simple trainers, simulation provides reliable and effective learning opportunities [7]. An innovative approach to education and the need to improve curricula suggest that more frequent use of simulation in education can lead to improved knowledge, self-confidence, and practical skills of nursing students, without exposing patients to unnecessary risk. In order to achieve specific learning outcomes, many simulation methods are used, from technical skills to communication and teamwork skills [8]. Simulation is an effective method to train role-change skills in an interdisciplinary team, and also to train and improve communication skills prior to working in the healthcare sector [9]. Simulation-based education makes it possible for healthcare team members to develop and improve their communication skills. Ineffective communication can lead to events which otherwise could have been prevented by the application of simulation in education. Teaching professional communication in simulated environments can help not only to promote effective communication skills and teamwork but can also contribute to improving the quality of patient care [10]. The utilisation of medical simulation as an educational tool is becoming increasingly common in nursing education worldwide. The review and analysis of the literature prove that a number of studies confirm the effectiveness of simulation in the improvement of clinical skills, knowledge and attitudes of nursing students, thus supporting its quick adoption [11]. The results of the meta-analysis conducted by Shin S. et al. indicate that education provided through simulation is more effective than education utilising traditional methods, and can also point teachers in the right direction in terms of recommended conditions for the education of nursing students. In the analysis of subgroups, they found that simulation education in nursing was beneficial in terms of the magnitude of effects, which were assessed based on the outcomes in psychomotor skills and knowledge [12].

Nowadays, students can access enormous volumes of information, which can be overwhelming, difficult to categorise 
and put into use, and which often is inconsistent with their clinical practice experience. Simulation provides students with a safe environment to integrate and apply their knowledge. Based on certain data, simulation improves student performance in terms of their knowledge and skills. Simulation provides an environment in which all nursing students can actively engage in a variety of aspects of patient care, not only as regards their health but also in social situations involving patients and their families [4]. Research conducted by Stewart et al. shows that students who participated in simulation classes were more competent at providing patients with holistic care. According to some people, however, thus far there have been few well-conducted studies on the impact of educational simulation on the process of linking knowledge to clinical practice and on the quality of patient care $[5,13]$.

The ability to establish situations in which lesson scenarios can be conducted with a strictly defined educational goal is an important advantage of simulation. This, in turn, leads to mastery in a specific field and the verification or confirmation of students' skills and competences $[14,15]$. Simulation facilitates practising critical thinking and making clinical decisions in a simulated environment, which translates into improved skills which are desirable in a real environment [16]. Simulation is regarded as a very effective learning and teaching method, appropriate given the quickly changing nursing education environment. The positive effects of simulation have been confirmed in a number of studies. Unfortunately, there are still barriers to the use of educational simulation in nursing which concern many areas, including teachers being insufficiently convicted of and prepared to the implementation and use of simulation-based education.
These obstacles need to be removed to further develop simulation-based education in nursing [17]. The literature review has demonstrated that educational simulation is a source of satisfaction for nursing students with participation in the educational process. It also increases their self-confidence, develops critical thinking, supports their psychomotor development and, taking into account the challenges faced by education, it can be a viable option to meet the educational needs of students. One crucial advantage of simulation-based education is the opportunity for students to acquire knowledge and skills in many ways. Still, there is too little research which would explicitly corroborate its effectiveness in nursing. Therefore, it is necessary to conduct further research in this field from the perspectives of both the teacher and the student $[18,19,20]$.

\section{CONCLUSIONS}

1. Education involving simulation is more effective than traditional learning methods. Not only does it improve students' performance in terms of their knowledge, skills and competences, but it also serves as a source of satisfaction for nursing students with their education, enhances their confidence and develops critical thinking.

2. Educational simulation in nursing makes it possible to conduct lesson scenarios with a strictly defined educational goal.

3. Nevertheless, there are too few scientific reports which would confirm the effectiveness of simulation-based education in nursing, giving rise to the need for further research in this field.

\section{Symulacja medyczna - innowacja w kształceniu pielęgniarek}

\section{WPROWADZENIE}

Zmiany dokonujące się w obszarze opieki zdrowotnej, rosnąca populacja osób starszych, a także działania ukierunkowane na doskonalenie jakości usług medycznych czy też nacisk na zwiększenie bezpieczeństwa pacjentów to wyzwania wymagające otwartego i szczerego dialogu pomiędzy organizacjami opieki zdrowotnej, nauczycielami i studentami. Wyzwania te wymagają odważnych i ryzykownych rozwiązań, konieczności wprowadzania innowacji w dążeniu do nabywania doświadczeń edukacyjnych, które zapewnią profesjonalną kadrę pielęgniarską a ostatecznie wysokiej jakości opiekę zdrowotną sprawowaną wobec pacjenta.

Innowacja nie jest nową koncepcją dla zawodu, gdyż pielęgniarki codziennie na całym świecie angażują się w innowacyjne działania, które wynikają z chęci doskonalenia jakości opieki nad pacjentami. Pielęgniarki wprowadzają innowacje także w celu pozyskiwania informacji, lepszych sposobów promowania zdrowia, zapobiegania chorobom, doskonalenia metod nauczania i uczenia się [1,2].
Wyzwania stojące przed współczesnym pielęgniarstwem są wieloaspektowe, obejmują zarówno niedobór kadry, jak i jakość kształcenia oraz praktyki klinicznej. Badania dowodzą, że czas jaki studenci spędzają na edukacji klinicznej niekoniecznie koreluje z wysokiej jakości nauką, która przygotowuje studentów do praktyki [3]. Nie ma także pewności, że ten czas składa się z bogatych doświadczeń edukacyjnych przygotowujących do przyszłej pracy [4]. Konieczność zaspokojenia istniejących potrzeb opieki zdrowotnej oraz aktualne wyzwania edukacyjne w pielęgniarstwie przyczyniły się do wzrostu wykorzystania symulacji medycznej w edukacji, jako innowacyjnej metody nauczania zapewnianiającej wysokiej jakości, spójnych i powtarzalnych doświadczeń klinicznych [5].

Wprowadzenie opartego na symulacji nauczania i uczenia się medycyny, pielęgniarstwa i opieki nad pacjentami jest jednym $z$ bardzo ważnych kroków w kształceniu pielęgniarek i położnych. Symulacja to termin odnoszący się do sztucznej rzeczywistości umiejscowionej w świecie prawdziwym; jest ukierunkowana na osiąganie celów edukacyjnych poprzez 
naukę empiryczną, zaś narzędzia symulacyjne stanowią alternatywę dla prawdziwych pacjentów. Symulacja zwiększa nie tylko kompetencje kadry pielęgniarskiej, ale także wpływa na poprawę bezpieczeństwa pacjentów. Wykorzystanie symulatorów rozwiązuje wiele problemów. Studenci mają możliwość na żądanie, w zależności od potrzeb, odtwarzać wiele sytuacji klinicznych związanych z opieką nad pacjentem w warunkach symulowanych, począwszy od procedur nieinwazyjnych po inwazyjne. Mogą oni doskonalić swoje umiejętności w środowisku bezpiecznym, wolnym od ryzyka.

\section{CEL PRACY}

Celem pracy była analiza wpływu symulacji edukacyjnej na poziom wiedzy, umiejętności i kompetencji studentów pielęgniarstwa.

\section{METODY}

$\mathrm{W}$ badaniach zastosowano metodę niesystematycznej analizy piśmiennictwa. Do analiz zaklasyfikowano literaturę, z której wyłoniono treści dotyczące wpływu symulacji edukacyjnej na proces kształcenia studentów pielęgniarstwa. Podczas kwalifikacji czasopism wykorzystano wyszukiwarkę Google Scholar. Korzystano $\mathrm{z}$ artykułów opublikowanych w elektronicznych bazach danych: EBSCOhost, MEDLINE, ScienceDirect. Do badań wybrano recenzowane artykuły opublikowane w latach 2015 - 2019. Ogółem przeanalizowano 65 artykułów angielskojęzycznych oraz 35 polskojęzycznych. Spośród 100 artykułów wybrano 19, które spełniały kryteria włączenia do dalszej analizy. W procesie kwalifikacji literatury użyto czterech słów kluczowych: symulacja, pielęgniarstwo, edukacja, innowacja.

\section{WYNIKI}

Symulacja jest nowoczesną metodą edukacyjną stosowaną zarówno w ośrodkach akademickich, jak i placówkach opieki zdrowotnej. Począwszy od bogatych w technologię scenariuszy symulacji o wysokiej wierności, po podstawowe szkolenia umiejętności przy użyciu prostych trenażerów, symulacja zapewnia solidne i skuteczne możliwości uczenia się [6]. Innowacyjne podejście do edukacji oraz potrzeba doskonalenia programów nauczania sugeruje, że częstsze stosowanie symulacji w procesie kształcenia może prowadzić do zwiększenia poziomu wiedzy, pewności siebie i umiejętności praktycznych studentów pielęgniarstwa, bez narażania na niepotrzebne ryzyko pacjentów. W celu osiągnięcia określonych efektów uczenia się, stosuje się szereg metod symulacji od umiejętności technicznych po umiejętności komunikacji i pracy zespołowej [7]. Symulacja jest skuteczną metodą ćwiczenia umiejętności zmiany roli w zespole interdyscyplinarnym, a także ćwiczenia i doskonalenia umiejętności komunikacyjnych przed wejściem w relację z pacjentem do opieki zdrowotnej [8]. Edukacja oparta na symulacji umożliwia członkom zespołów opieki zdrowotnej rozwijanie i doskonalenie umiejętności komunikacyjnych. Nieefektywna komunikacja może przyczynić się do zdarzeń, których można uniknąć poprzez wykorzystanie symulacji w edukacji. Uczenie komunikacji zawodowej w środowiskach symulacyjnych, może pomóc nie tylko w promowaniu skutecznych umiejętności komunikacyjnych, współpracy w zespole, ale też może przyczynić się do podnoszenia jakości opieki nad pacjentem [9]. Wykorzystanie symulacji medycznej jako narzędzia edukacyjnego staje się coraz bardziej powszechne w edukacji pielęgniarskiej na całym świecie. Przegląd i analiza literatury dowodzi, że czynnikiem przemawiającym za szybkim przyjęciem symulacji jest szereg badań potwierdzających jej skuteczność w podnoszeniu umiejętności klinicznych, wiedzy i postaw studentów pielęgniarstwa [10]. Wyniki metaanalizy prowadzonej przez Shin S. et al. wskazują, że edukacja prowadzona za pomocą symulacji jest bardziej efektywna niż edukacja realizowana $z$ pomocą metod tradycyjnych a także może ukierunkować nauczycieli pod względem warunków, w których powinno być prowadzone kształcenie studentów pielęgniarstwa. W analizie podgrup stwierdzili oni, że edukacja symulacyjna w pielęgniarstwie przynosiła korzyści pod względem wielkości efektów, które były oceniane na podstawie uzyskanych wyników zarówno w zakresie umiejętności psychomotorycznych, jak i posiadanej wiedzy [11].

Studenci mają dziś dostęp do ogromnej ilości informacji, które mogą być przytłaczające, trudne do kategoryzacji i zastosowania, a często są sprzeczne $\mathrm{z}$ ich doświadczeniem w praktyce klinicznej. Symulacja zapewnia studentom bezpieczne środowisko do integracji i wykorzystania ich wiedzy. Istnieją dane, które dowodzą, iż symulacja poprawia wyniki studentów w zakresie posiadanej wiedzy i umiejętności. Symulacja zapewnia warunki, w której wszyscy studenci pielęgniarstwa mogą aktywnie angażować się w różnorodne aspekty opieki nad pacjentami, w różnorodne sytuacje nie tylko zdrowotne, ale też społeczne pacjentów i ich rodzin [4]. Z badań przeprowadzonych przez Stewarta et al. wynika, że studenci, którzy uczestniczyli w zajęciach z wykorzystaniem symulacji posiadali wyższy poziom kompetencji do zapewnienia pacjentom holistycznej opieki. Jednak niektórzy są zdania, że jak dotąd nie ma zbyt wielu dobrze przeprowadzonych badań dotyczących wpływu symulacji edukacyjnej na proces wiązania wiedzy z praktyką kliniczną oraz jakość opieki sprawowanej wobec pacjenta [5,12].

Istotną zaletą symulacji jest możliwość zapewnienia sytuacji, w których można przeprowadzić scenariusze zajęć o ściśle określonym celu edukacyjnym, co w konsekwencji prowadzi do opanowania określonej wiedzy oraz zweryfikowania i ewentualnego potwierdzenia umiejętności i kompetencji studentów [13,14]. Symulacja zapewnia możliwość praktykowania krytycznego myślenia, a także podejmowania decyzji klinicznych w środowisku symulacyjnym, co przekłada się na doskonalenie umiejętności pożądanych w środowisku rzeczywistym [15]. Symulacja jest uważana za bardzo skuteczną metodę nauczania i uczenia się, odpowiednią do szybko zmieniającego się środowiska edukacji pielęgniarskiej i w wielu badaniach potwierdzono pozytywne aspekty symulacji. Niestety 
nadal można dostrzec występowanie barier w wykorzystaniu symulacji edukacyjnej w pielęgniarstwie, które dotyczą wielu obszarów, m.in. niedostatecznego przekonania i przygotowania nauczycieli do wdrażania i wykorzystywania edukacji opartej na symulacji, a które należy rozwiązać, aby dalej rozwijać edukację opartą na symulacji w pielęgniarstwie [16]. Z przeglądu literatury wynika, że symulacja edukacyjna jest źródłem satysfakcji studentów pielęgniarstwa $\mathrm{z}$ udziału w procesie kształcenia, zwiększa ich pewność siebie, rozwija krytyczne myślenie, wspiera ich rozwój psychomotoryczny a biorąc pod uwagę wyzwania, przed którymi stoi edukacja, symulacja może być realnym rozwiązaniem, aby sprostać potrzebom edukacyjnym studentów. Niezmiernie ważną zaletą edukacji opartej na symulacji jest możliwość nabywania wiedzy i umiejętności studentów na wiele sposobów, jednak nadal istnieje zbyt mała liczba badań, które potwierdzałyby w sposób jednoznaczny skuteczność edukacji z wykorzystaniem symulacji w pielęgniarstwie i konieczne jest prowadzenie badań na temat edukacji opartej na symulacji zarówno z perspektywy nauczyciela, jak i studenta $[17,18,19]$.

\section{WNIOSKI}

1. Edukacja realizowana $z$ wykorzystaniem symulacji medycznej jest bardziej skuteczna niż tradycyjne metody uczenia się. Nie tylko poprawia wyniki studentów w zakresie posiadanej wiedzy, umiejętności i kompetencji ale też jest źródłem satysfakcji studentów pielęgniarstwa $\mathrm{z}$ udziału w procesie kształcenia, zwiększa ich pewność siebie, rozwija krytyczne myślenie.

2. Symulacja edukacyjna w pielęgniarstwie umożliwia zapewnienie sytuacji, w których można przeprowadzić scenariusze zajęć o ściśle określonym celu edukacyjnym.

3. Nadal istnieje zbyt mała liczba doniesień naukowych, które potwierdzałyby w sposób jednoznaczny skuteczność edukacji symulacyjnej w pielęgniarstwie, stąd konieczne jest dalsze podejmowanie badań w tym zakresie.

\section{REFERENCES/PIŚMIENNICTWO}

1. Kaya N, Turan N, Aydin GQ. A Concept Analysis of Innovation in Nursing. ProcediaSocial and Behavioral Sciences. 2015: 195; 1674 - 1678.

2. Kaya N, Turan N, Aydin GQ. Innovation in Nursing: A Concept Analysis. J Comm Pub Health Nursing. 2016; 2:1-4.

3. Fulton CR, Clark C, Dickinson S. Clinical hours in nurse practitioner programs equals competence: Fact or misnomer? Nurse Educator. 2017; 42 (4): 195-198.

4. LeFlore JL, Thomas PE. Educational changes to support advanced practice nursing education. J Perinat Neonatal Nurs. 2016; 30 (3): 187-190.

5. Rutherford-Hemming T, Nye C, Coram C. Using simulation for clinical practice hours in nurse practitioner education in the United States: A systematic review Nurse Educ Today. 2016; 37: 128-135.

6. Sweeney N, Rollins MC, Gantt L, et al. Development and Reliability Testing of the Sweeney-Clark Simulation Evaluation Rubric. Clinical Simulation in Nursing. 2019.

7. Parry M, Fey MK. Simulation in Advanced Practice Nursing. Clinical Simulation in Nursing. 2019; 26:1-2.

8. Green M, Tariq R, Green P. Improving patient safety through simulation training in anesthesiology: Where are we now? Anesthesiology Research and Practice. 2016; 5:1-12.

9. Guido-Sanz F, Desiree A. Diaz, Anderson M, Gonzalez L, Houston A., Role Transition and Communication in Graduate Education: The Process. Clinical Simulation in Nursing. 2019; 26: 11-17.

10. Lee J, Oh PJ. Effects of the use of high-fidelity human simulation in nursing education: A meta-analysis. J of Nurs Educ. 2015; 4 (9): 501-50.

11. Shin S, Park J-H, Kim J-H. Effectiveness of patient simulation in nursing education: Meta-analysis. Nurse Educ Today. 2015; 35, 1: 176-182.

12. Adamson K. A systematic review of the literature related to the NLN/Jeffries Simulation Framework. Nurs Educ Perspect. 2015; 36 (5): 281-291.

13. Sujatta $S$, Oberärztin L. First of all: Do not harm! Use of simulation for the training of regional anaesthesia techniques: Which skills can be trained without the patient as substitute for a mannequin. Best Pract Res Clin. Anaesthesiol. 2015; 29 (1): 69-80.

14. Starkweather A, Sargent L, Nye C, Albrecht T, Cloutier R, Foster A. Progressive assessment and competency evaluation framework for integrating simulation in nurse practitioner education. J Nurse Pract. 2017; 13 (7): 301-310.

15. Larue C, Pepin J, Allard E. Simulation in preparation or sub-stitution for clinical placement: A systematic review of the literature. J Nurse Educ and Pract. 2015: 5(9): 132-140.

16. Park H, Yu S. .Policy issues in simulation-based nursing education and technology development. Health Policy and Technology. 2018; 7, 3: 318-321.

17. Cant RP, Cooper. SJ. Use of simulation-based learning in undergraduate nurse education: An umbrella systematic review. Nurse Educ Today. 2017; 49: 63-71.

18. Tjoflåt I, Våga $B B$, Søreide $E$. Implementing simulation in a nursing education programme: a case report from Tanzania. Adv Simul (Lond). 2017; 3,2:17.

19. Anderson M, Campbell SH, Nye C, Diaz D, Boyd T. Simulation in Advanced Practice Education: Let's Dialogue!! Clinical Simulation in Nursing. 2019; 26: 81-85.

Manuscript received/Praca zgłoszona do czasopisma: 29.08.2019

Manuscript accepted/Praca zaakceptowana do druku: 24.10.2019

Translation/Tłumaczenie: Joanna Girzelska 